\title{
MENTHALAQ ISTRI SEDANG HAID TINJAUAN DALAM HADITS
}

\author{
Syaikhu
}

IAIN Palangka Raya, Kalimantan Tengah, Indonesia syaikhu.ahmad.h@gmail.com

Received:03-03-2019; Revised:13-05-2019; Accepted: 18-05-2019

\begin{abstract}
ABSTRAK
Problematika dalam rumah tangga yang di latar belakangi banyak hal, mengakibatkan kecendrungan seorang suami dan istri lebih cepat mengambil keputusan perceraian. Pernikahan bagi umat manusia adalah sesuatu yang sangat sakral dan mempunyai tujuan yang sakrat pula, dan tidak terlepas dari ketentuan-ketentuan yang ditetapkan oleh syari'at. Tujuan yang hakiki dalam sebuah penikahan adalah untuk mewujudkan rumah tangga yang sakinah yang selalu dihiasi mawaddah dan rahmah. Bila rumah tangga yang didirikan telah terjadi ketimpangan seperti salah satu kedua belah pihak suami istri sudah berkurang rasa cintanya, menipisnya rasa saling percaya, mengutamakan egois masing-masing, saling tidak menghormati, dan sebagainya, sebuah keluarga demikian sudah tidak dapat dipertahankan lagi keutuhannya dan jalan yang terbaik adalah memutuskan pernikahan dengan perceraian. Hal ini dibenarkan oleh Islam kalau memang benar-benar sulit diperbaiki dan dipertahankan demi kebaikan masa depan kedua belah pihak. Legalisasi yang diberikan oleh syara' terhadap pensyari'atan thalaq itu juga didukung oleh dalil logika, di mana apabila kondisi antara suami dan istri itu memburuk sehingga jika sepasang suami dan istri itu dipaksa untuk mempertahankan perkawinannya, justru akan menimbulkan kemafsadat-an dan ke-mudharat-an saja. Permasalahan yang dihadapai bagaimana kalau istri dalam keadaan haid?. Oleh sebab itu, perlu adanya pemahaman ulang tentang hal thalaq suami terhadap istri yang sedang haid, yang penulis bahas menurut Hadits Nabi Muhammad Saw beserta dengan pendapat para ulama.
\end{abstract}

Kata Kunci : Menthalaq istri, Haid

\section{A. Pendahuluan}

Perceraian atau talak dalam hukum Islam pada prinsipnya boleh tapi dibenci oleh Allah, namun perceraian merupakan alternative terakhir yang boleh ditempuh manakala kehidupan rumah tangga tidak bisa dipertahankan lagi.Islam menunjukkan agar sebelum terjadi perceraian, ditempuh usaha-usaha perdamaian antara kedua belah pihak, karena ikatan perkawinan adalah ikatan yang paling suci dan kokoh. ${ }^{1}$

Islam memberikan hak talak hanya kepada suami, karena keinginan suami lebih kuat untuk tetap melanjutkan tali perkawinan yang telah banyak mengorbankan harta. Atas pertimbangan tersebut, disamping suami memiliki akal dan sifat yang lebih sabar dalam menghadapi sikap dan perilaku istri yang tidak disenangi, seorang suami tidak akan bersikap terburu-buru untuk memutuskan bercerai hanya karena perasaan marah atau sifat buruk istrinya yang cenderung membuat susah dirinya. ${ }^{2}$ Hak menjatuhkan talak melekat pada orang yang

\footnotetext{
${ }^{1}$ Ahmad Rofiq, Hukum Islam di Indonesia, (Jakarta: PT. Raja Grafindo, cet I, 1995), hlm. 268

${ }^{2}$ Sayyid Sabiq, Fikih Sunnah 4, (Jakarta: Cakrawala Publishing, 2009), hlm. 9.
} 
menikahinya. Apabila hak menikahi orang perempuan untuk dijadikan sebagai istri melekat pada seorang suami, maka yang berhak menjatuhkan talak adalah orang laki-laki yang menikahinya (suami). ${ }^{3}$

Seperti keterangan di atas, talak merupakan hak laki-laki sebagai seorang suami. Oleh karena itu ia berhak mentalak istrinya secara langsung atau mewakilkannya kepada orang lain. Jika seorang suami menyerahkan urusan istrinya kepada orang lain selain istrinya, maka hal itu tetap sah dan hukum yang berlaku padanya adalah hukum jika ia menyerahkan urusannya itu kepada istrinya. ${ }^{4}$

Syari'at menjadikan talak sebagai jalan yang sah untuk bercerainya suami istri, namun syara' membenci terjadinya perbuatan ini. Adapun sebab-sebab dan alasan terjadinya talak itu adakalanya menyebabkan kedudukan talak menjadi wajib, haram, sunnah, mubah dan makruh. Sebagaimana yang disebutkan Imam Al-Jaziri dalam kitabnya menyatakan bahwa fuqaha telah membagi talak dengan melihat ibarat yang berbeda-beda dari sifat hukumnya, mereka membagi hukum talak menjadi wajib, haram, makruh, mandub dan jaiz. ${ }^{5}$ Di samping legalitas syara' yang terdapat dalam al-Quran dan Sunnah di atas, para ulama juga telah menyepakati dalam bentuk ijma' terhadap kebolehan menjatuhkan talak tersebut.

\section{B. Teks Hadits}

Adapun Hadits yang berkaitan dengan Hukum Talak, di antaranya : pada Bab "Haram Menceraikan Wanita yang sedang Haid tanpa persetujuannya. Jika seseorang Melanggar, Cerai tersebut tetap jatuh. Tetapi ia diperintahkan untuk meruju’ Istrinya Kembali”.

Hadis dimaksud adalah hadis yang ditakhrij oleh al-Nasai sebagai berikut:

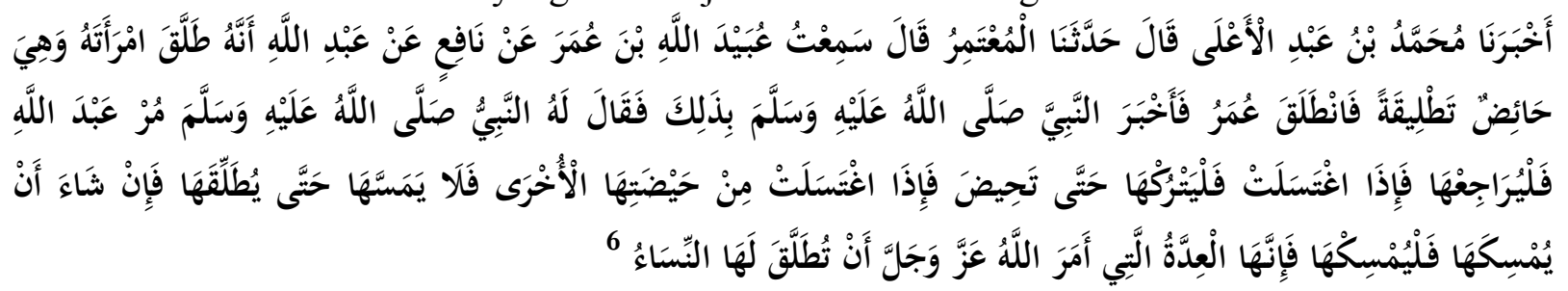

Arti matan hadis :

Bahwasanya Ibnu Umar, r.a mentalak istrinya dalam keadaan haid di zaman Rasulullah saw. Lalu Umar bertanya kepada Rasulullah saw. Tentang kejadian itu. Maka beliau menjawab : "suruhlah ia meruju'nya, hendaklah ia menahan istrinya sampai bersih, kemudian haid lalu bersih lagi, bila ia mau tahanlah (teruskanlah) dengan istrinya itu, atau mentalaknya juga bila ia mau hendaknya sebelum di campuri, 'iddah itulah yang Allah perintahkan bila perempuanperumpuan itu sudah di talak."

Hadis di atas ditakhrij oleh al-Nasai melaui sanad Muhammad ibn Abd al-A'la ke Mu'tamir ke Ubaidillah ibn Umar ke Nafi' ke Abdullah ibn Umar lalu ke Nabi saw. Walaupun

\footnotetext{
${ }^{3}$ Rahmat Hakim, Hukum Perkawinan Islam, (Bandung: Pustaka Setia. 2000), hlm, 155

${ }^{4}$ Syaikh Hasan Ayyub, Fikih Keluarga, (Jakarta: Pustaka Al-Kautsar, 2001), hlm. 295

5 Abdurrrahmân al-Jazirî, Kitab al-Fiqh 'ala Madzahib al- 'Araba'ah, Juz IV, (Beirut Lebanon : Daar alKutub al-'Ilmiyah 1972), hlm. 284

${ }^{6}$ Imam Al-Nasa'iy, Sunan al-Nasa'iy, Juz.4 (Beirut: Dar al- Fikr, t.th), h. 180 hadist nomor 3396
} 
pada dasarnya ada banyak versi mengenai hadis ini baik dari segi sanad maupun redaksi matannya. Dengan demikian, dalam penelitian sanad, periwayat yang akan diteliti secara berurut adalah sebagai berikut: periwayat pertama adalah 'Abd Allah (Ibn 'Umar); periwayat kedua adalah Nafi'; Periwayat ketiga adalah 'Ubaid Allah ibn 'Umar; periwayat keempat adalah Mu'tamir; periwayat kelima adalah Muhammad ibn 'Abd al-A'la; dan periwayat keenam adalah al-Nasa'iy.

1. 'Abd Allah

Nama lengkapnya adalah 'Abdullah ibn 'Umar ibn al-Khattab ibn Nufail al-Qurasy al-'Adawiy. Ia masuk Islam bersama ayahnya, dan saat itu ia belum balig, dan ada yang mengatakan ia lebih dahulu memeluk Islam dari ayahnya. Selain itu ia adalah orang yang terkenal akan kesalehannya. Ia juga termasuk salah seorang dari kelompok. "al-abādilah" yang alim. Ibn 'Umar meriwayatkan hadis-hadis langsung dari Nabi saw.; Umar ibn Khattab (ayahnya); Zaid (pamannya); Hafsah (saudara perempuannya) Abu Bakar al-Siddiq, 'Usman ibn 'Affan, Ali ibn Abli Thalib; Zaid ibn Tsabit dan lain-lain. Adapun hadis-hadisnya, diriwayatkan pula oleb Nafi, Aslam (pembantu 'Umar), Zaid dan Khalid (keduanya anak Aslam), 'Urwah ibn Zubair dan lain-lain.

2. Nafi' (w. 117 H.)

Nama aslinya adalah Abar Syahar. Ia adalah maula/pembantu 'Abdullah ibn Umar alKhattab yang berasal dari Naisaburi, ada juga yang mengatakan ia berasal dari Maghribi (Maroko). Nafi meriwayatkan hadis-hadis Nabi saw., bersumber dari 'Abd Allah ibn 'Umar; dalam hal ini Basyar ibn 'Umar al-Zahraniy meriwayatkan bahwa Malik ibn Anas pernah berkata bahwa "apabila aku mendapatkan hadis yang datangnya dari Nafi' yang bersumber dari 'Abd Allah ibn Umar, maka aku tidak peduli lagi dengan yang lainnya." Menurut Imam Ibn Hirasy dan al-Ijliy bahwa Nafi' adalah seorang yang tsiqah. Sedangkan menurut Imam al-Bukhari Nafi' adalah seorang yang paling baik sanadnya. Hadis-hadis Nafi diriwayatkan juga oleh 'Ubaid Allah ibn 'Umar, 'Ata' al-Khurasaniy, 'Ata' ibn Khalid al-Makhzumiy, Uqail ibn Khalid al-Aily. 'Ali ibn al-Hakim al-Bunaniy. dan lain-lain.

3. Ubaid Allah ibn 'Umar (w. $145 \mathrm{H}$ )

Nama lengkapnya adalah 'Ubaid Allah ibn 'Umar ibn Hafsah ibn 'Asim ibn 'Umar ibn al-Khattab. Hadis-hadis yang diriwayatkannya bersumber dari Nafi', 'Umar ibn Nafi (anak.Nafi') al-Qasim ibn Muhammad ibn Abi Bakar, dan lain-lain. Adapun hadis-hadisnya diriwayatkan pula oleh Mu'tamir, Yahya ibn Abi Zaidah al-Qatthan, Abu Khalid al-Ahmar, 'Abd al-Wahhab al-Tsaqafi, Uqbah ibn Khalid al-Sukuny, Isa ibn Yunus, dan lain-lain. Menurut Imam Ahmad ibn Hanbal bahwa 'Ubaidillah adalah seorang yang tsabit, kuat hafalannya, serta banyak meriwayatkan hadis-hadis Nabi saw.

4. Mu'tamir (w. $187 \mathrm{H}$ )

Nama lengkapnya adalah Mu'tamir ibn Sulaiman ibn Tarkhan al-Taimiy. Hadis-hadis yang diriwayatkannya bersumber dari Ubaid Allah ibn Umar, Kahmas ibn al-Hasan, Muhammad ibn 'Umar ibn 'Alqamah, Ishaq ibn Suwaid al-Adawiy, dan lain-lain. Sedangkan hadis-hadisnya diriwayatkan juga oleh Muhammad Ibn 'Abd al-A'la, al-Tsauri, Ibnu Mubarak, 'Abd al-Rahman ibn Mahdiy, 'Abd al-Razzaq, 'Abd Allah ibn Ja'far alRaqiy, dan lain-lain. Menurut Ibnu Sa'ad bahwa Mu'tamir adalah seorang yang Tsiqah, demikian juga dengan pendapat Ibnu Ma'in.

5. Muhammad ibn Abd al-A'la (w. 245 H.)

Nama lengkapnya adalah Muhammad ibn' Abd al-A'la al-San'aniy al-Qaisiy. Hadis-hadis yang diriwayatkannya berasal dari Mu'tamir, Yazid ibn Zarr, Abu Bakar ibn 
'Iyas; Sufyan ibn 'Uyainah, Isma'il ibn Aliyah, dan lain-lain. Adapun hadis-hadisnya diriwayatkan pula oleh oleh al-Nasa'iy, al-Turmuziy, Ibnu Majah, dan lain-lain. Salian itu Imam Muslim meriwayatkan, hadis darinya sebanyah. 25 buah hadis. Sedangkan Imam alNasa'iy berkata bahwa Muhammad ibn 'Abd al-A'la adalah seorang yang baik.

6. al-Nasa'iy

Nama lengkapnya adalah Abu 'Abd al-Rahman Ahmad ibn Syu'aib ibn Bahr. Nama Nasa'iy yang berada dibelakang namanya tersebut adalah merupakan penisbatan pada kota kelahirannya di Khurasan. Menurut sebagian ulama bahwa dari segi hafalan, Imam alNasa'iy lebih unggul dari Imam Muslim. Selain itu, ia adalah seorang yang dikenal dengan kewaraan dan ketaqwaannya. ${ }^{7}$

Berdasarkan penjelasan tersebut di atas, maka dapat dipahami bahwa hubungan antara 'Abd Allah ibn Umar dengan Nafi' bukan saja hubungan antara guru dan murid, tapi lebih dari itu bahwa Nafi' adalah maula 'Abd Allah ibn 'Umar. Dengan demikian, persambungan sanad antara keduanya sangat erat dan tidak dapat diragukan.

Adapun hubungan dengan 'Ubaid Allah ibn Umar adalah hubungan guru dan murid. Sebab selain keduanya dimungkinkan untuk bertemu karena selisih umur keduanya memungkinkan, juga karena periwayat (Nafi') dan yang menerima riwayat ('Ubaid Allah), di antarai oleh harf "عن" yang memungkinkan terjadi pertemuan. Selain itu tidak ada indikasi penyembunyian informasi (tadlis) yang dilakukan oleh perlwayat tersebut.

Sedangkan 'Ubaid Allah dengan Mu'tamir, tampaknya terdapat hubungan antara guru dan murid juga. Sebab kata "سمعت" yang digunakan oleh Mu'tamir, adalah merupakan petunjuk bahwa ia (Mu'tamir) telah mendengar sendiri riwayat hadis tersebut dari 'Ubaidillah. Demikian juga halnya antara Mu'tamir dengan Muhammad ibn 'Abd al-A'la. Antara keduanya juga terjadi hubungan guru dan murid yang pernah bertemu satu sama lainnya. Sebab metode periwayatan hadis yang digunakan adalah "حدثن" yang mengindikasikan bahwa ia (Muhammad ibn 'Abd al-A'la) mendengar sendiri dari gurunya (Mu'tamir).

Mengenai Muhammad ibn 'Abd al-A'la dengan lmam al-Nasa'iy, maka hubungan keduanya adalah antara guru dan murid. Sebab metode "أخبرنا" yang digunakan oleh Imam alNasa'iy menunjukkan bahwa gurunya (Muhammad ibn 'Abd al-A'la) menyampaikan dengan menghadapkan riwayatnya kepada periwayat/mukharrij al-Hadis, yaitu al-Nasa'iy. ${ }^{8}$

Dengan adanya persambungan sanad dan dengan adanya ketsiqahan (adil dan dabith)nya para periwayat, serta tidak adanya penyembunyian informasi maka hadis yang diriwayatkan oleh al-Nasa'iy dari 'Abd Allah ibn Umar tersebut dapat dikategorikan sebagai hadis yang shahih. Al-Albani juga menilai hadits di atas shahih.

\section{Asbabul Wurud Hadits}

Ibnu Umar mentalak istrinya dalam keadaan haid di zaman Rasulullah saw. Lalu Umar bertanya kepada Rasulullah saw. Tentang kejadian itu. Maka beliau menjawab :

\footnotetext{
${ }^{7}$ Fathurrahman, Mustalahul Hadis (Bandung: al-Ma'arif, 1995), h. 334
}

\footnotetext{
${ }^{8}$ M. Syuhudi Ismail, Kaedah Kesahihan Sanad Hadis (Jakarta: Bulan Bintang, 1995), h. 70
} 
"suruhlah ia meruju'nya, hendaklah ia menahan istrinya sampai bersih, kemudian haid lalu bersih lagi, bila ia mau tahanlah (teruskanlah) dengan istrinya itu, atau mentalaknya juga bila ia mau hendaknya sebelum di campuri, 'iddah itulah yang Allah perintahkan bila perempuan-perumpuan itu sudah di talak.

Memperhatikan periwayat Hadis tersebut, Abdullah bin Umar lahir pada tahun kedua atau ketiga dari kenabian, masuk Islam ketika ia masih dalam usia 10 tahun bersama ayahnya. Ia berhijrah ke madinah lebih dulu dari pada ayahnya. Pada perang uhud ia masih kecil usianya, sehingga tidak di izinkan Rasullullah untuk mengikutinya kecuali peperangan- peperangan berikutnya . Ia selalu ikut bertempur bersama Nabi Muhammad saw dalam perang khandak dan peperangan sesudahnya. Bahkan sesudah nabi wafat, ia masih aktif dalam berbagai peperangan untuk kepentingan Islam.

Abdullah bin Umar adalah anak kedua dari Umar bin Al-Khattab dan saudara kandung Hafshah Umm Al-Mu'minin. Abdullah bin Umar termasuk seorang sahabat yang tekun dan berhati hati dalam meriwayatkan hadits. Ia juga meriwayatkan hadits sekitar 2.630 buah Abdullah bin Umar meninggal dunia di Mekah pada tahun 73 H/693 M dalam usia 87 tahun.

Hadis di atas setelah diteliti dari segi sanadnya, teryata memiliki kwalitas sahih. Penilaian ini didasarkan atas adanya indikasi bahwa seluruh Periwayatnya adalah siqah walaupun hadis tersebut diriwayatkan secara maknawi, namun dari segi matannya juga memiliki kualitas sahih, karena tidak ada indikasi ia bertentangan dengan syarat-syarat kesahihan suatu hadis.

\section{Kandungan Hukum dan Pendapat Ulama}

Hukum yang terkandung dalam hadits Ibnu Umar : Haram menjatuhkan talak dalam masa istri sedang berhaid. Para imam mazhab sepakat bahwa talak yang di jatuhkan pada masa haid setelah disetubuhi atau pada masa suci setelah di setubuhi hukumnya haram. Imam Malik berpendapat, bahwa menjatuhkan talak dalam keadaan haid kedua , haram juga. Pendapat inilah yang di pandang shahih oleh golongan Syafi'iyah.

Menthalak dalam masa haid, berarti mentalak dengan cara yang tidak di benarkan oleh syara'. Karenanya, tertolak. Kalau di pandang sah, tentulah diterima, tetapi ini berlawanan dengan nash. Sabda Nabi saw, yang terkandung dalam hadits diatas. "suruhlah dia supaya merujikinya" ", itulah yang menjadi pegangan untuk tidak mensahkan talak dalam masa berhaid.

Menurut Hadis di atas, Rasulullah Saw memerintahkan agar dalam menjatuhkan thalaq, memperhatikan apakah istri dalam keadaan suci atau dalam keadaan haid. ${ }^{9}$

Apabila seseorang berbicara tentang masalah haid, maka hal itu pasti berkaitan dengan perempuan yang telah mulai beranjak remaja dan dewasa, sebab perempuan yang masih berada di bawah umur (kurang lebih sembilan tahun), dan perempuan yang telah memasuki masa monopouse, tidak ada kaitannya dengan darah haid tersebut. Dalam QS. Al-Baqarah (2) : 222 dikatakan bahwa 'haid itu adalah sesuatu yang kotor ....' Berdasarkan ayat ini, muncul anggapan bahwa perempuan yang sedang mengami masa haid harus dihindari dan dijauhi. Ada banyak pendapat tentang ini. Imam Syafii mengatakan bahwa pergaulan suami istri dalam keadaan haid tetap saja berjalan seperti

\footnotetext{
${ }^{9}$ Ahmad Kuzari, Nikah Sebagai Perikatan (Jakarta; Fajar interpratama offest,1995), h. 133
} 
biasa kecuali melakukan dukhul (hubungan suami-istri). Ini didasarkan pada pernyataan yang besumber dari Umm al-Mu'minin, Aisyah r.a.: الذه كل شيئ الآ فرجها

Sedangkan menurut Abu Hanifah dan Imam Malik bahwa yang harus dihindari adalah antara pusar dan lutut, seperti yang dikemukakan oleh Umm al-Mu'minin ra. Bahwa Nabi saw. Bersenang-senang dengan istrinya sementara mereka dalam keadaan haid. Sementara menurut sahabat Ibn 'Abbas, bahwa yang harus dihindari adalah seluruh badan istri yang sedang haid, sebab menurut Ibn 'Abbas bahwa ayat yang ditunjuk di

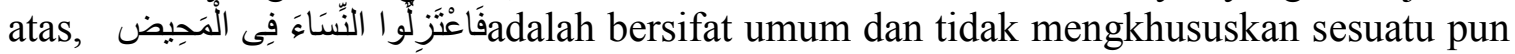
dari tubuh istri.

Talak dalam keadaan istri sedang haid atau nifas disebut dengan talak bid‘ $i$ karena mereka mendapatkan mudarat berupa lamanya waktu menunggu masa 'iddah. Sedangkan talak kepada seorang istri yang suci yang sebelumnya sudah dicampuri dan belum tampak tanda kehamilan dikategorikan dalam talak bid'i karena dengan begitu akan menimbulkan penyesalan ketika ternyata istri hamil.

Talak bid'i, menurut ulama Hanafi memiliki dua pendapat : pertama, disunnahkan untuk rujuk kembali. Pendapat ini merupakan pendapat yang dha'if. Kedua wajib, karena laki-laki yang menjatuhkan talak bid'i dianggap melakukan maksiat perbuatan, dan maksiat tersebut bisa dihilangkan dengan cara merujuk kembali si istri. Adapun atsar dari maksiat tersebut adalah memperpanjang masa iddah istri, maka jika istri rela terhadap adanya perpanjangan masa 'iddahnyadiperbolehkan untuk tidak merujuknya kembali. Apalagi jika diantara keduanya sudah saling enggan untuk bersama kembali, atau jika suami merujuknya malah akan menyakiti istri. ${ }^{11}$

Malikiyah membagi talak bid'i menjadi dua yaitu haram dan makruh. Talak bid‘ $i$ haram yaitu talak yang dijatuhkan kepada istri yang sudah dicampuri dalam tiga keadaan. Pertama, talak ketika istri dalam keadaan haid atau nifas. Kedua, talak tiga sekaligus, baik ketika suci maupun haid. Ketiga, talak yang dijatuhkan setelah talak yang pertama dengan perkataan ,kamu tertalak setengah, atau ,tanganmu tertalak'. Talak bid'i makruh adalah talak dalam dua keadaan. Pertama, talak dalam masa suci yang dalam masa tersebut telah dicampuri. Kedua, menjatuhkan dua talak sekaligus. ${ }^{12}$ Diharamkan talak ketika istri dalam keadaan haid. Namun jika hal itu terjadi, maka talak tetap sah. Jika suami tetap menalaknya, maka wajib untuk rujuk kembali.

Syafi'iyah berpendapat bahwa hukum merujuk istri ketika telah terjadi talak bid'i adalah sunnah. Pendapat ini berbeda dengan pendapat Malikiyah dan Hanafiyah yang mewajibkan rujuk ketika terjadi talak bid'i, mereka berpendapat bahwa amr dalam hadits tersebut menunjukkan arti wajib, berarti harus dilaksanakan. Menurut Hanabilah talak yang dijatuhkan suami ketika istri dalam keadaan haid, atau dalam keadaan suci yang sudah dicampuri dalam masa suci tersebut, merupakan talak bid'i haram.

Dengan demikian dapat disimpulkan bahwa talak bid'i termasuk talak yang dilarang. Larangan tersebut dikarenakan talak dilakukan pada waktu-waktu yang menghalangi istri dapat langsung memulai masa 'iddahnya, yaitu ketika istri haid dan ketika istri dalam masa suci yang telah dicampuri pada masa suci tersebut. Pada keadaan tersebut jika suami menjatuhkan talak, maka istri akan mengalami masa iddah yang lebih

${ }^{10}$ Muhammad Ali al-Shabuniy, Rawai' al-Bayan Tafsir Ayat al-Ahkam min Al-Qur'an, Juz I (Mekah: tp., tth.), h. 229

${ }^{11}$ Abd al-Rahman al-Jaziri, al-Fiqh 'ala al-Madzahib al-Arba'ah, ( Mesir : Dar al-Hadith, 2004) h. 239-240.

${ }^{12}$ Abd ar-Rahman al-Jaziri, al-Figh 'ala al-Madzhahib al-Arba'ah..., h 233. 
panjang dibandingkan ketika ia ditalak pada masa suci. Sekalipun dilarang, namun talak ini tetap sah sehingga mengurangi jumlah talak yang dimiliki oleh suami.

Sebagian ulama' mengatakan tidak sah, diantaranya adalah Abdullah bin 'Umar, Sa'id bin Musayyab, Thawus, Dzahiriyah, dan Ibnu Taimiyah. Mereka berpendapat bahwa setiap talak yang menyalahi talak sunni adalah talak bid'i, sedangkan perkataan Rasululllah bahwa setiap yang bid'ah adalah dhalalah. Talak bid'i menyalahi syariat Allah yang telah disebutkan dalam Al-Qur'an. Juga berdasarkan hadits yang diriwayatkan 'Aisyah ,setiap amal yang tidak ada perintah di dalamnya maka ditolak.

Ibnu Hazm berpendapat dalam al-Muhalla mengenai talak pada waktu haidh dan saat suci yang sudah digauli sebagai berikut: Tidak diperbolehkan seorang suami menalak istrinya dalam waktu haidh, dan pada waktu suci yang telah digauli. Adapun talak satu atau dua dalam keadaan suci yang telah digauli, atau pada waktu haid, maka talak tersebut tidak jatuh."13

Dari pendapat Ibnu Hazm dapat kita pahami, bahwa talak pada waktu haid dan suci yang sudah digauli itu termasuk dalam kategori talak bid'i. Selain hukumnya haram talaknya juga tidak jatuh, Ibnu Hazm tidak setuju menyamakan talak bid'i kedalam pengertian talak secara umum karena talak tersebut tidak sesuai dengan perintah Allah.

Selain itu tidak diperbolehkannya talak yang dijatuhkan kepada istri dalam keadaan haid akan memperlama masa 'iddah, yang mana talak seperti ini akan menyulitkan istri. Sedangkan talak yang dijatuhkan kepada istri dalam keadaan suci yang sudah digauli, barangkali akan menimbulkan penyesalan dari pihak suami kalau sudah jelas kehamilannya, sebab suami terkadang mentalak istri disebabkan tidak kunjung hamil. Dan apabila suami menyesal, maka tidak mudah untuk memperbaiki lagi, sehingga menyulitkan anak di kemudian hari. ${ }^{14}$

\section{Hukum Menceraikan Istri dalam Keadaan Haid}

Asbab wurud al-hadis dari hadis di atas sangat jelas dari redaksinya sendiri, yaitu kasus 'Abd Allah ibn Umar yang menceraikan istrinya dalam keadaan haid. Peristiwa ini dilaporkan 'Umar (bapaknya) kepada Nabi Muhammad saw. Mendengar laporan itu, Nabi saw. tampaknya "marah" dan memerintahkan 'Abd Allah untuk meruju' istrinya kembali dan bila telah suci, maka biarkan ia sampai haid, dan bila suci lagi, maka janganlah "disentuh" sampai ia diceraikan, atau tetap dipertahankan (tidah diceraikan). Demikianlah 'iddah yang diperintahkan Allah dalam menceraikan istri.

Dari hadis tersebut dapat dipahami bahwa mentalak isti dalam keadaan haid itu adalah suatu perbuatan dosa. Oleh karena itu, untuk dapat terlepas dari dosa tipe ini, caranya hanya dengan merujuk kembali istrinya itu. Para ulama telah bersepakat bahwa tidak boleh menceraikan istri dalam keadaan haid tersebut, kecuali dalam tiga keadaan sebagai berikut:

1. Jika perceraian terjadi sebelum berkumpul dengan istri. Dalam kondisi seperti ini, maka seorang istri boleh diceraikan dalam keadaan haid. Sebab dalam contoh kasus seperti ini tidak ada 'iddah bagi istri yang diceraikan itu (Q5. 33:49). Dengan demikian, perceraian tipe ini tidak menyalahi firman Allah: فطلقو هن لعدنهن

2. Jika haid terjadi dalam keadaan hamil, maka seseorang boleh mentalak istrinya jika telah terjadi ketidak-cocokan, dan hal ini tidak menyalahi firman Allah ataupun sunnah Rasul, sebab tidak. ada keterangan dalam Alquran maupun sunnah yang menolak kemungkinan

\footnotetext{
${ }^{13}$ Ibnu Hazm, Al Muhalla, Juz X (Beirut: Dar al-Fikr, t.th), 161.

${ }^{14}$ Taqiyuddin Abi Bakar, Kifayatul Akhyar, Juz II (Semarang : Toha Putra, t.th),185.
} 
terjadinya haid pada perempuan hamil. Selain iitu bahwa bila seseorang mentalak istrinya dalam keadaan hamil, itu berarti mentalaknya pada saat perempuan tersebut dapat menghadapi masa 'iddahnya, baik dalam keadaan haid ataupun dalam keadaan suci, karena واولات : masa 'iddahnya adalah dengan kehamilan/setelah melahirkan seperti firman Allah (الأحمال اجلهن ان يضعن حملهن ....... (QS. 65 : 4). Oleh karena itu, tidak mengapa seseorang mentalak istrinya dalam keadaan hamil, sekalipun setelah ia melakukan $d u k h u l$.

3. Jika talak itu dilakukan atas iwad (penggantian), maka dalam keadaan seperti ini seorang suami boleh menceraikan istrinya dalam keadaan haid. Keadaan seperti ini pernah terjadi pada zaman Nabi Muhammad saw., yaitu ketika seorang perempuan (Jamilah binti Salul) mengadukan suaminya (Tsabit ibn Qais) tentang ketidak-cocokan di antara mereka berdua, maka Nabi bertanya kepada perempuan tersebut tentang kesanggupannya untuk "mengkhulu" (mengganti apa yang telah diberikan oleh suaminya), dan karena perempuan tersebut menyanggupi, maka Nabi saw. pun mensahkan perceraian mereka berdua. Dalam kasus ini Nabi saw. Tidak mempersoalkan apakah perempuan itu dalam keadaan haid atau tidak. ${ }^{15}$

Menurut Ibn al-Munzir dan Ibn 'Abd al-Barr, bahwa seseorang yang menceraikan istrinya dalam keadaan haid, maka talaknya itu tetap sah, walaupun ia tetap berdosa ketika melakukan hal yanq demikian itu, dan talak tipe ini disebut talak bid'ah.

Tanpa mengurangi penghormatan kepada kedua ulama tersebut, namun bila pendapat tersebut dihadapkan dengan hadis Nabi saw. di atas, maka sudah barang tentu orang akan lebih cenderung kepada apa yang telah dicontohkan oleh Nabi saw. sebagai sunnah/hadis tersebut. Apalagi talak seperti itu disebut sebagai talak bid'ah, dan setiap bidah oleh Nabi saw. disebut sebagai dalalah (sesat). Selain itu bahwa apa yang menjadi ketetapan Rasul itu, tidak boleh ada pilihan lain bagi orang-orang yang beriman kecuali harus mengikuti apa yang telah ditetapkan oleh Rasulullah saw. itu (QS. 37:36), apalagi ketetapan Rasul saw. (menurut kesepakatan ulama) dalam bentuk qauliyahnya tersebut, setelah diteliti, ternyata ia berkualitas sahih, baik. dari segi sanad ataupun matannya.

Dalam Sahih Muslim yang disyarahkan oleh Imam al-Nawawi disebutkan bahwa sudah merupakan ijma ulama bahwa haram hukumnya menceraikan istri dalam keadaan haid tanpa ada kerelaan dari istri yang diceraikan itu, dan apabila perceraian itu tetap saja dilangsungkan, maka suami yang menceraikan itu wajib untuk, meruju' kembali istrinya itu. ${ }^{16}$

Dari apa yang dikemukakan di atas, dapat dipahami bahwa menceraikan istri dalam keadaan haid, bukanlah merupakan sesuatu yang haram secara mutlak. Perceraian itu dapat saja berlangsung bilamana keduanya (suami istri) itu tidak dapat lagi melaksanakan hukum-hukum Allah dengan baik, yang demikian itu tidak ada dosa bagi sang istri asalkan ia rida' dengan kejadian yang menimpanya itu (Q5. 2:229).

Perceraian itu dapat saja dilakukan walaupun dalam keadaan haid, apabila persengketaan antara suami istri itu tidak dapat lagi didamaikan oleh Hakam dari kedua belah pihak (QS. 4:35), bahkan agaknya dalam kasus seperti ini, bercerai itu wajib hukumnya. Selain itu, karena

\footnotetext{
${ }^{15}$ Muhammad Ali al-Shabuniy, op. cit., h. $326-327$

${ }^{16}$ Al-Imam al- Nawawiy, Shahih Muslim bi Syarh al-Nawawiy (Beirut: Dar al-Fikr, 1978), h. 60
} 
perceraian yang dapat diruju' hanya. dua kali (QS. 2:229), maka dalam kasus talak bain seorang istri dapat saja diceraikan walaupun ia masih berada dalam keadaan haid.

\section{Prinsip Talak Dalam Hukum Islam}

Talak berasal dari bahasa Arab, yaitu al-Talaq. Kata al-Talaq merupakan bentuk masdar dari kata talaqa-yat luqu-talaqan yang mempunyai arti lepas dari ikatannya. Secara etimologi kata al-Talaq berarti : laqayda 'alaiha wa kazalika al-khaliyyah (tidak ada ikatan atasnya dan juga berarti meninggalkan). Dengan redaksi lain, 'Ali ibn Muhammad Al-Jurjaniy ${ }^{17}$ mengemukakan pengertian etimologi dari kata al- Talaq itu dengan : Izalat al-qayd wa altakhliyyah (menghilangkan ikatan dan meninggalkan). Dalam pengertian etimologi kata al-Talaq tersebut digunakan untuk menyatakan: ,melepaskan ikatan secara hissiy, namun 'urf mengkhususkan pengertian al-Talaq itu kepada: ,melepaskan ikatan secara ma'nawi. ${ }^{18}$

Sedangkan pengertian talak secara terminologi telah dikemukakan oleh ulama fikih. Menurut al-Sayyid al-Bakar (ulama dari golongan syafi'iyyah), talak adalah : elepaskan akad pernikahan dengan menggunakan lafal berikut : al-Talaq, al-Firaq dan al-Sarrah. Ulama Malikiyah mengemukan yakni Suatu sifat hukum yang mengangkat halalnya bersenang-senang antara seorang suami dengan istrinya, yang mana apabila hal itu telah dilakukan dua kali maka diharamkan atasnya (untuk menikahi) sebelum ia menikah dengan orang lain.

Dalam istilah fiqh talak mempunyai dua arti, yaitu arti yang umum dan arti yang khusus. Talak menurut arti yang umum ialah segala macam bentuk perceraian baik yang dijatuhkan oleh suami, yang ditetapkan oleh Hakim, maupun perceraian yang jatuh dengan sendirinya atau perceraian karena meninggalnya salah seorang dari suami atau istri.

Talak dalam arti yang khusus ialah perceraian yang dijatuhkan oleh suami. ${ }^{19}$ Dengan pengertian talak tersebut, maka jelas yang dimaksud dengan talak adalah melepaskan ikatan antara suami-istri, sehingga diantara keduanya tidak berhak berkumpul lagi dalam arti tidak boleh mengadakan hubungan suami-istri tanpa diadakan rujuk terlebih dahulu dalam masa iddahnya.

\section{Dasar Hukum Talak}

Talak sebagai salah satu yang disyaratkan dalam agama Islam, tentunya telah mendapatkan legalitas oleh syara'. Dasar pensyariatan hukum talak tersebut terdapat dalam al-Quran dan Sunnah, serta telah disepakati oleh Ulama dalam bentuk ijma' terhadap legalitasnya.

Di antara dasar hukum talak yang terdapat dalam al-Qur'an :

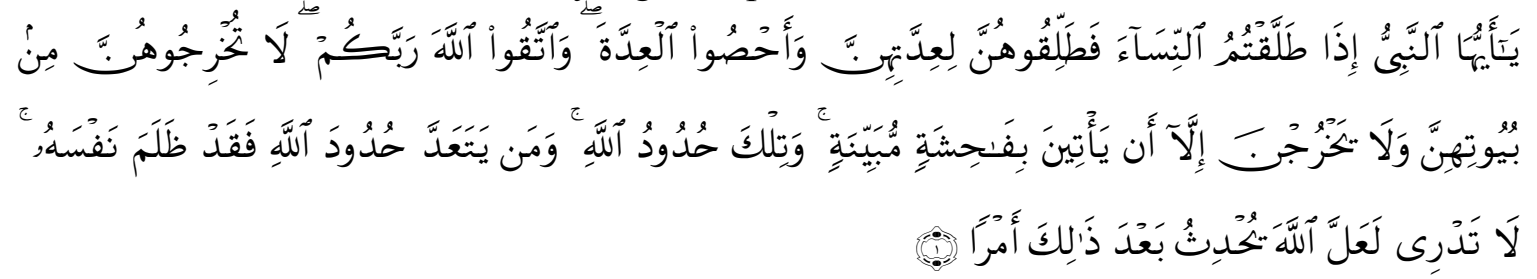

\footnotetext{
${ }^{17}$ Ali bin Muhammad al-Jurjaniy, Kitab al-Ta'rifat, cet. Ke-3 (Beirut: Dar al-Kutub al'Ilmiyyah, 1998), h. 141

${ }^{18}$ Wahbah al-Zuhayliy, al-Fiqh al-Islamiyah wa Adillatuhu, cet. Ke-3, Juz 7 (Damaskus, Dar alFikr,

${ }^{19}$ Abd. Rahman Ghazaly, Fiqh Munakahat, (Jakarta: Kencana, 2010), 191.
} 1989), h.356. 
Hai Nabi, apabila kamu menceraikan istri-istrimu maka hendaklah kamu ceraikan mereka pada waktu mereka dapat (menghadapi) iddahnya (yang wajar)dan hitunglah waktu iddah itu serta bertakwalah kepada Allah Tuhanmu. Janganlah kamu keluarkan mereka dari rumah mereka dan janganlah mereka (diizinkan) ke luar kecuali mereka mengerjakan perbuatan keji yang terang. Itulah hukum-hukum Allah, maka sesungguhnya dia telah berbuat zalim terhadap dirinya sendiri. Kamu tidak mengetahui barangkali Allah mengadakan sesudah itu sesuatu hal yang baru. $(Q S .65: 1)^{20}$

Ayat di atas secara jelas menguraikan petunjuk atau aturan tentang waktu dan tata cara menjatuhkan talak, kepada Nabi Muhammad SAW. Akan tetapi, meskipun yang di khitab dalam ayat tersebut hanya Nabi Muhammad SAW, namun menurut para mufassir, kandungan hukum yang terdapat dalam ayat itu tetap menjangkau dan berlaku bagi umatnya.

Dalam mengomentari pengkhususan khitab terhadap Nabi Muhammad SAW dalam ayat di atas, Abu Bakar, sebagaimana yang dikutip oleh Abi Bakr Ahmad al-Razi alJashshash, mengemukakan sebagai berikut: Abu Bakar berkata: pengkhususan khitab ayat terhadap Nabi Muhammad SAW membawa beberapa kemungkinan pengertian;

a. Sudah diketahui bahwa hukum atau ketentuan apa saja yang ditujukan kepada Nabi Muhammad SAW, juga ditujukan kepada umatnya. Sebab umatnya tersebut diperintahkan untuk mengikuti apa saja yang diperintahkan kepada Nabi SAW, kecuali beberapa hal yang dikhususkan kepada Nabi SAW.

b. Pada awal potongan ayat tersebut, di taqdirkan kalimat: Ya ayyuha al-Nabi qul li ummatika idza thallaqtum al-nisa'....(Hai Nabi, katakanlah kepada umatmu: Apabila kamu menceraikan Istri-istrimu...)

c. Biasanya, apabila yang dikhitab itu adalah Pemimpinnya, maka pengikutnya telah termasuk di dalamnya. ${ }^{21}$

Muhammad Sulaiman 'Abdillah al-'Asyqar dan Ibn Katsir berpendapat bahwa didahulukannya khitab tersebut kepada Nabi Muhammad SAW hanya berfungsi sebagai penghormatan dan memuliakan Nabi Muhammad SAW. ketentuan yang terdapat dalam ayat di atas, menurut kedua mufassir tersebut, juga berfungsi bagi Umatnya, sebab setelah khitab itu ditujukan kepada Nabi SAW, Allah SWT menujukannya kepada Nabi SAW dan umatnya, yaitu dengan menggunakan khitab plural pada kata "tallaqtum".

Begitu juga firman Allah SWT dalam surat al-Baqarah [2] ayat 231; Dalam ayat ini Allah SWT menjelaskan bahwa seorang suami yang menjatuhkan kepada istrinya hendaklah tidak menganiaya istrinya dengan cara mengupayakan agar istrinya tersebut berada dalam masa 'idah yang panjang. Ayat tersebut di atas merupakan kritikan keras terhadap kasus yang dipraktekkan oleh Tsabit Ibnu Basyar, seorang laki-laki dari golongan Ansar, dimana ia menjatuhkan talak istrinya namun ketika masa 'iddah-nya tinggal dua atau tiga hari lagi, lalu ia rujuk kepada istrinya, kemudian ia kembali menjatuhkan talak istrinya untuk yang kedua dan begitu seterusnya sehingga istrinya tersebut selalu berada dalam masa 'iddah selama sembilan bulan, dengan maksud menganiayanya. Oleh karena itulah sehingga Allah menurunkan ayat diatas. Demikian asbab al-nuzul ayat tersebut menurut Syaikh Sayis. $^{22}$

\footnotetext{
${ }^{20}$ Departemen Agama RI, Al-Qur'an dan Terjemahnya, (Bandung : Diponegoro, 2008), (65 : 1), 558

${ }^{21}$ Abu Bakr Ahmad al-Raziy al-Jassas, Ahkam al-Qur'an, Juz 3, (Beirut: Dar al-Fikr, 1993), h.677.
}

${ }^{22}$ Muhammad 'Ali al-Sayis, Tafsir Ayat al-Ahkam, Jilid 1, (Beirut: Dar al-Kutub al'Ilmiyyah, t.th.), h.154. 
Juga dalam surah al-Baqarah, 2: 229) Artinya: "Talak (yang dapat dirujuki) dua kali. Setelah itu boleh rujuk lagi dengan cara yang ma'ruf atau menceraikan dengan cara yang baik." Dalil dari as-Sunnah Diantaranya sebuah al-Hadits yang diriwayatkan dari Ibnu Umar ra. bahwasannya dia menalak istrinya yang sedang haid.

Di samping legalitas syara' yang terdapat dalam al-Quran dan Sunnah di atas, para ulama juga telah menyepakati dalam bentuk ijma' terhadap kebolehan menjatuhkan talak tersebut. Legalisasi yang diberikan oleh syara' terhadap pensyari'atan talak itu juga didukung oleh dalil logika, di mana apabila kondisi antara suami dan istri itu memburuk sehingga jika sepasang suami dan istri itu dipaksa untuk mempertahankan perkawinannya, justru akan menimbulkan ke-mafsadat-an dan ke-mudharat-an saja. Dalam kondisi seperti itu tidak logis mempertahankan perkawinan tersebut, sebab hanya akan memperpanjang situasi buruk, mafsadah dan ke-mudharat-an tersebut.

Berdasarkan uraian di atas dapat dipahami bahwa meskipun hukum asal dari talak itu adalah mahzur (dilarang) kecuali karena alasan-alasan yang sudah masuk ke dalam kategori hajah. Namun walau bagaimanapun, talak memang disyari'atkan dalam Islam berdasarkan beberapa ayat dan hadis Nabi SAW tersebut di atas.

\section{Hukum Talak, Rukun dan Syaratnya}

Menurut Imam Nawawi, hukum perceraian ada empat macam, yaitu ada kalanya perceraian itu hukumnya wajib, haram, makruh, atau ada kalanya hukum perceraian itu mandub (sunah), dengan uraian sebagai berikut : ${ }^{23}$

- Wajib jika pejabat berwenang telah mengutus dua orang juru damai (hakam) untuk mendamaikan, tapi setelah diupayakan ternyata menurut mereka berdua yang terbaik (mashlahat) adalah bercerai, maka perceraian adalah wajib.

- Makruh jika tidak terjadi masalah dalam rumah tangga, tapi salah satu suami atau istri menuntut cerai tanpa ada sebab yang jelas.

- Haram jika (1) istri dalam keadaan haid sedangkan ia tidak menuntut cerai dengan ganti rugi dan tidak ada permintaan untuk diceraikan; (2) istri dalam keadaan suci dan sudah "digauli" oleh suami namun belum jelas apakah istri hamil atau tidak; (3) jika suami memiliki beberapa orang istri yang telah diatur giliran masing-masing; lantas suami menceraikan salah satu istrinya sebelum ia menunaikan giliran untuk istri tersebut.

- Mandub jika sang istri tidak bisa menjaga kehormatan dirinya atau salah satu atau keduaduanya merasa tidak bisa menjalankan kewajiban yang telah diatur oleh syara'. diperlukan.

Kalangan Ulama' Hanafiyah berpendapat bahwa talak itu terlarang kecuali bila

Sedang menurut madzhab Syafi'i membedakan hukum talak menjadi empat yaitu:

a. Wajib yaitu seperti talaknya orang yang tidak bisa bersetubuh.

b. Haram yaitu menjatuhkan talak sewaktu istri dalam keadaan haid.

c. Sunnah yaitu seperti talaknya orang yang tidak bisa melaksanakan kewajibannya sebagai suami karena tidak ada keinginan sama sekali kepada istrinya.

d. Makruh seperti terpeliharannya semua peristiwa tersebut di atas.

Ulama Hanabilah memperinci hukum talak sebagai berikut:

a. Haram yaitu talak yang tidak diperlukan atau talak tanpa alasan. Karena merugikan bagi suami-istri dan tidak ada kemaslahatan yang mau dicapai dengan perbuatan talaknya itu.

\footnotetext{
${ }^{23}$ Al-Minhaj Syarah Al-Nawawiy 'ala Shahih Muslim, h. 61
} 
b. Wajib yaitu talak yang dijatuhkan oleh pihak hakam dalam perkara syiqoq yakni perselisihan istri yang tidak dapat didamaikan lagi, dan kedua belah pihak memandang bahwa perceraian adalah jalan terbaikdalam menyelesaikan persengketaan mereka.

c. Sunnah yaitu talak yang dijatuhkan kepada istri yang sudah keterlaluan dalam melanggar perintah Allah.

d. Mubah yaitu talak yang terjadi hanya apabila diperlukan, missal karena kelakuan istri jelek. $^{24}$

Terjadi perbedaan pendapat dikalangan ulama mengenai penetapan rukun talak. Menurut ulama Hanafiyyah, rukun talak itu adalah sebagaimana yang dikemukakan oleh alKasani sebagai berikut: ," Rukun talak adalah lafal yang menjadi penunjukan terhadap makna talak, baik secara etimologi yaitu al-takhliyyah (meninggalkan atau membiarkan), alirsal (mengutus) dan raf al-Qayyid (mengangkat ikatan) dalam kategori lafal-lafal lainnya pada lafal kinayah, atau secara syara' yang menghilangkan halalnya ("bersenang-senang" dengan) istri dalam kedua bentuknya (raj'iy dan ba'in), atau apapun yang menempati posisi lafal.

Berdasarkan keterangan di atas dapat dipahami bahwa rukun talak itu dalam pandangan ulama Hanafiyah hanya satu, yaitu lafal yang menunjukkan makna talak, baik secara etimologi dalam kategori sarih atau kinayah, atau secara syar'i, atau tafwid (menyerahkan kepada istri untuk menjatuhkan talaknya).

Sedangkan menurut ulama Malikiyah, rukun talak itu ada empat, yaitu orang yang berkompeten menjatuhkan talak, ada kesengajaan menjatuhkan talak, wanita yang dihalalkan dan adanya lafal, baik sarih maupun kinayah. Sedangkan menurut ulama Syafi'iyyah dan Hanabilah rukun talak tersebut ada lima, yaitu orang yang menjatuhkan talak, adanya lafal talak, adanya kesengajaan menjatuhkan talak, adanya wanita yang dihalalkan dan menguasai istri tersebut. ${ }^{25}$

Syarat-syarat talak yang harus dipenuhi tersebut diklasifikasikan kepada tiga kategori, yaitu ada yang terdapat pada suami, terdapat pada istri dan ada yang terdapat pada lafal itu sendiri.

a. Syarat-syarat yang terdapat pada suami

Adapun syarat-syarat yang terdapat pada suami itu adalah:

1) Suami harus orang yang berakal Orang yang akalnya rusak atau tidak waras tidak boleh menjatuhkan talak dan talaknya tidak sah. Yang termasuk dalam pengertian tidak waras akalnya di sini adalah gila, mabuk karena meminum khamr atau sesuatu yang memabukkan, tidur, pingsan, epilepsi, sedangkan dia tidak mengetahui apa yang diucapkannya.

2) Suami itu telah Baligh. Oleh karena itu, apabila anak kecil menjatuhkan talak maka talaknya tidak sah.

3) Atas kehendak sendiri. Maka tidak sah talak yang dijatuhkan oleh seseorang yang dipaksa menjatuhkan talak sementara dirinya sendiri tidak berkehendak.

b. Syarat-syarat yang terdapat pada wanita adalah bahwa wanita tersebut adalah miliknya atau masih berada dalam masa 'iddah talak. Oleh karena itu, apabila seorang laki-laki

\footnotetext{
${ }^{24}$ Al-Hamdani, Risalah Nikah, 203

${ }^{25}$ Sayyid Abi Bakr, I'anat al-Talibin, Jilid 4 (Beirut: Dar Ihya'’ al-Turats al-'Arabi, t.th.), h.2.
} 
menjatuhkan talak kepada wanita yang bukan istrinya atau tidak berada dalam masa 'iddah maka talaknya tidak sah. ${ }^{26}$

c. Syarat yang terdapat pada lafal adalah:

1) Menggunakan lafal yang bermakna talak, baik secara etimologi maupun 'urf atau baik melalui tulisan maupun isyarat yang dapat dipahami.

2) Orang yang menjatuhkan talak itu memahami makna lafal itu.

\section{Macam-macam Talak}

3) Lafal talak itu disandarkan kepada istrinya dalam kalimat.

Ada banyak pembagian, jenis atau macam-macam talak, namun dalam makalah ini hanya sebagaiannya saja yang dikemukakan. Dari segi waktu menjatuhkan talak, maka talak terbagi menjadi dua yaitu :

a. Talak Sunniy adalah talak yang terjadi dengan sesuai ketentuan syari'at Islam. Contohnya, seorang suami mentalak istrinya (dimana antara suami istri tersebut telah melakukan hubungan suami istri/ba'da $d u k h u l$ ), talak dijatukan dengan satu kali talak pada saat istri dalam keadaam suci dan tidak disetubuhi selama waktu suci tersebut.Hal ini berdasarkan firman Allah SWT:

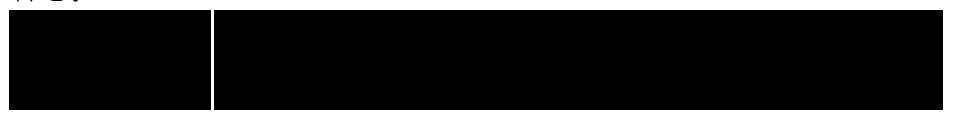

Maksudnya bahwa talak disyari'atkan ajarkan Islam satu kali talak, kemudian dilanjutkan dengan rujuk (kembali). Kemudian di talak untuk kedua kali, kemudian dilanjutkan dengan rujuk lagi, setelah itu, jika seorang suami yang menceraikan istrinya setelah rujuk kedua ini, maka terdapat pilihan antara bersama dengan cara baik atau berpisah dengan cara yang baik. ${ }^{27}$

b. Talak bid'iy adalah talak yang tidak sesuai dengan ketentuan syari'at Islam seperti suami yang menalak istri sebanyak tiga kali dengan satu ucapan atau menalak tiga kali secara terpisah-pisah dalam satu tempat. Contohnya: Seorang suami berkata, Engkau tertalak, engkau tertalak, engkau tertalak, atau seorang suami menalak istri ketika haid, nifas atau ketika sedang suci tapi sudah disetubuhi pada masa suci tersebut. Para ulama sepakat bahwa talak bid'iy diharamkan dan bagi yang melakukannya, dia berdosa. ${ }^{28}$

Walaupun ulama sepakat atas haramnya menalak istri pada waktu haid, namun berbeda pendapat dalam hal apakah talak yang diucapkan suami pada saat istri haid itu terjadi atau tidak. Jumhur ulama berpendapat bahwa talak pada waktu haid itu jatuh. Alasannya, bahwa dalam hadis| yang diriwayatkan An Nasa'i, dinyatakan bahwa Ibnu Umar yang menceraikan istrinya dalam keadaan haid disuruh rujuk kepada istrinya oleh Rasulullah Saw, dan rujuk mengandung arti bahwa sebelumnya telah terjadi talak.

\section{E. Penutup}

Terlepas dari pendapat mana yang harus dipegang oleh suami-istri dalam kehidupan rumah tangga, yang jelas bahwa Allah swt. memerintahkan agar setiap suami istri hendaknya mau menggauli istrinya secara patut. Kemudian apabila suami tidak menyukai lagi istrinya, maka Allah menganjurkan agar hendaklah suami mau bersabar, "karena mungkin sesuatu yang tidak disukai itu, jusrtu Allah menjadikan kebaikan yang banyak padanya". Walaupun suami disuruh

\footnotetext{
${ }^{26}$ Ibnu Rusyd, Bidayah al Mujtahid, Juz 2, 61.

${ }^{27}$ Fiqh Al-Sunnah, Jilid II, h. 225

${ }^{28}$ Ibid., h. 226
} 
oleh Allah untuk bersabar dalam menyikapi lstrinya, namun hal itu bukan berarti apabila ketidakcocokan yang terjadi di antara keduanya tidak ada lagi jalan keluarnya, jalan keluar yang Allah berikan adalah bercerai/talaq. Sekalipun bercerai itu adalah sesuatu yang tidak disukai oleh Allah, namun dalam melakukan perceraian itu hendaklah dengan cara yang baik, dan harus sesuai dengan aturan yang ada dalam Alquran dan sunnah.

Talak bid'i merupakan talak yang dilarang namun talaknya tetap jatuh. Akan tetapi jika kemafsadahnya yang diperoleh lebih banyak seperti memperlama masa iddah, yang mana talak seperti ini akan menyulitkan istri serta talak yang dijatuhkan kepada istri dalam keadaan suci yang sudah digauli, barangkali akan menimbulkan penyesalan dari pihak suami kalau sudah jelas kehamilannya, maka lebih baiknya jika talak tersebut tidak dilakukan oleh suami.

Dalam bergaul dengan seorang istri yang berada dalam kondisi bawaan (haid.) itu, Islam memberikan petunjuk pelaksanaannya. Seperti tidak diperbolehkan menceraikannya dalam keadaan haid dan melakukan hubungan suami istri, seperti yang disebutkan di atas. Walaupun dalam hal ini (menceraikan istri dalam keadaan haid), para ulama membolehkan, tapi dengan beberapa syarat tertentu. Dengan demikian, pelarangan menceraikan istri dalam keadaan haid, tidak berlaku secara mutlak bagi setiap istri yang berada dalam keadaan tersebut, tapi tergantung pada kondisi yang ada dan masalah yang muncul pada saat itu.

\section{DAFTAR PUSTAKA}

Ahmad Kuzari, Nikah Sebagai Perikatan (Jakarta; Fajar interpratama offest,1995)

Ahmad Rofiq, Hukum Islam di Indonesia, (Jakarta: PT. Raja Grafindo, cet I, 1995)

Abdurrrahmân al-Jazirî, Kitab al-Fiqh 'ala Madzahib al-'Araba'ah, Juz IV, (Beirut Lebanon : Daar al-Kutub al-'Ilmiyah 1972)

Al-Imam al- Nawawiy, Shahih Muslim bi Syarh al-Nawawiy (Beirut: Dar al-Fikr, 1978)

Ali bin Muhammad al-Jurjaniy, Kitab al-Ta'rifat, cet. Ke-3 (Beirut: Dar al-Kutub al'Ilmiyyah, 1998)

Abd. Rahman Ghazaly, Fiqh Munakahat, (Jakarta: Kencana, 2010)

Abu Bakr Ahmad al-Raziy al-Jassas, Ahkam al-Qur'an, Juz 3, (Beirut: Dar al-Fikr, 1993)

Departemen Agama RI, Al-Qur'an dan Terjemahnya, (Bandung : Diponegoro, 2008)

Fathurrahman, Mustalahul Hadis (Bandung: al-Ma'arif, 1995)

Ibnu Hajar Al-Asqalani, Bulug Al-Maram min Adillah Al-Ahkam, (Progaram digital Maktabah Syamilah 2008)

Imam Al-Nasa'iy, Sunan al-Nasa 'iy, Juz.4 (Beirut: Dar al- Fikr, t.th)

Ibnu Hazm, Al Muhalla, Juz X (Beirut: Dar al-Fikr, t.th)

Muhammad Fu'ad Al-Baqiy, Al-Lu'lu' wa Al-Marjan, Jilid I, h. 445 (Progaram digital Maktabah Syamilah 2008).

M. Syuhudi Ismail, Kaedah Kesahihan Sanad Hadis (Jakarta: Bulan Bintang, 1995)

Mohammad Asmawi, Nikah Dalam Perbincangan dan Pperbedaan (Yogyakarta: Cet I, 2004)

Muhammad Ali al-Shabuniy, Rawai' al-Bayan Tafsir Ayat al-Ahkam min Al-Qur'an, Juz I

(Mekah: tp., tth.) 
Muhammad 'Ali al-Sayis, Tafsir Ayat al-Ahkam, Jilid 1, (Beirut: Dar al-Kutub al'Ilmiyyah, t.th.)

Rahmat Hakim, Hukum Perkawinan Islam, (Bandung: Pustaka Setia. 2000)

Taqiyuddin Abi Bakar, Kifayatul Akhyar, Juz II (Semarang : Toha Putra, t.th)

Sayyid Sabiq, Fikih Sunnah 4, (Jakarta: Cakrawala Publishing, 2009)

Syaikh Hasan Ayyub, Fikih Keluarga, (Jakarta: Pustaka Al-Kautsar, 2001)

Sayyid Abi Bakr, I'anat al-Talibin, Jilid 4 (Beirut: Dar Ihya'’ al-Turats al-'Arabi, t.th.)

Wahbah al-Zuhayliy, al-Fiqh al-Islamiy wa Adillatuh, cet. Ke-3, Juz 7 (Damaskus, Dar al-Fikr, 1989) 